АРХІВНІ МАТЕРІАЛИ ЯК ДЖЕРЕЛО ДОСЛІДЖЕННЯ
ПРОБЛЕМИ ПІДГОТОВКИ ФІЛОЛОГІВ
У ВИЩИХ НАВЧАЛЬНИХ ЗАКЛАДАХ УКРАЇНИ (1850-1917 РР.)

\title{
ARCHIVAL MATERIALS AS A SOURCE FOR INVESTIGATING THE PROBLEM OF PHILOLOGISTS' TRAINING IN HIGHER EDUCATIONAL INSTITUTIONS OF UKRAINE (1850-1917)
}

У статті досліджується висвітлення організаційно-методичних засад підготовки майбутніх фрілологів у вищих навчальних закладах України в 1850-1917 роках в архівних джерелах. Наводиться опис архівних джерел, які відображають організаційно-методичні засади підготовки майбутніх фрілологів у вищих навчальних закладах України в 1850 1917 роках. Автором проаналізовано архівні фонди Державного історичного архіву України, Державного архіву Київської області, Державного архіву Харківської області, Державного архіву Одеської області, Державного архіву Львівської області, Державного архіву Чернівецької області, а також цисррові архіви бібліотек Одеського національного університету імені І.І. Мечникова та Харківського національного університету імені В.Н. Каразіна. Досліджено архівні інтернет-джерела, а саме: фонди Ягелонської електронної бібліотеки (Jagiellońska Biblioteka Cyfrowa), неприбуткової бібліотеки «lнтернет-архів» (Internet Archive), Великопольскої електронної бібліотеки (Digital Library of Wielkopolska), Федерація електронних бібліотек (Federacja Bibliotek Cyfrowych), які у вільному доступі містять рідкісні оциоровані історичні документи, статті, видання польською та німецькою мовами. Матеріалами дослідження є архівні джерела, які висвітлюють діяльність вищих навчальних закладів України в 1850-1917 роках. Ці матеріали містять інформацію щодо організаційно-методичних засад підготовки майбутніх фрілологів у період, що досліджується: звіти університетів та фракультетів, офріційне листування, програми підготовки, розклади занять, матеріали інспектувань тощо. Огляд архівних джерел дає змогу цілісно охарактеризувати організаційнометодичні засади підготовки майбутніх фрілологів у вищих навчальних закладах України в 1850-1917 роках. Джерельна база дослідження містить джерела, які були відібрані в процесі аналізу та вивчення документів в архівних установах України та електронних архівів, що є невід'ємною частиною сучасного дослідження.
Ключові слова: архівні джерела, архівні установи, організаційно-методичні засади, підготовка фрілологів, джерельна база.

The article investigates the organizational and methodical basis for the preparation of future philologists in higher educational institutions of Ukraine in 1850-1917 in archival sources. The article describes the archival sources reflecting organizational and methodical bases of preparation of the future philologists in higher educational institutions of Ukraine in 1850-1917. The author analyzes the archival fonds of the State Historical Archive of Ukraine, the State Archive of Kyiv Oblast, the State Archive of Kharkiv Oblast, the State Archive of Odesa Oblast, the State Archive of Lviv Oblast, the State Archive of Chernivtsi Oblast, as well as digital archives of the libraries of the I.I. Mechnikov Odesa National University and V.N. Karazin Kharkiv National University. The following Internet archival sources have been studied: Jagiellońska Biblioteka Cyfrowa, Internet Archive, Digital Library of Wielkopolska, Federation of Electronic Libraries (Federacja Bibliotek Cyfrowych), which contain rare digitized historical documents, articles and editions in Polish and German languages in free access. The research materials are archival sources covering the activities of Ukrainian higher education institutions in 1850-1917. These materials contain information on the organizational and methodological basis for the preparation of future philologists during the researched period: reports of universities and faculties, official correspondence, curriculums, class schedules, materials of inspections, etc. The review of archival sources allows us to characterize the organizational and methodological basis for the training of future philologists in higher educational institutions of Ukraine in 1850-1917. The source base of the research includes materials that were selected in the process of the analysis and investigation of documents in archival institutions of Ukraine and electronic archives, which are an integral part of modern research.

Key words: archival sources, archival institutions, organizational and methodical basis, training of philologists, source base. імені профресора Євгена Петухова

Херсонського державного університету
Постановка проблеми в загальному вигляді. Архівні джерела $є$ основним джерелом інорормації історико-педагогічних досліджень. Вивчення архівних матеріалів дає змогу всебічно дослідити та розкрити основні положення дослідження, проаналізувати стан та розвиток суспільства, науки, освіти тощо.

Аналіз останніх досліджень і публікацій. Дослідженню проблеми становлення та розвитку освіти присвятили свої роботи вітчизняні й зарубіжні вчені, зокрема: В. Алексєєв, С. Балашов,
В. Базилевич, Д. Богиня, О. Грішнова, О. Глузман, М. Долішній, С. Дорогунцов, Й. Завадський, В. Куценко, С. Струмилін, К. Суботіна, Т. Шульц, Б. Шелегеда, Г. щетиніна та ін.

Деякі історико-педагогічні аспекти фрілологічної освіти у вищій школі України містять роботи, які присвячені аналізу діяльності університетів України (XIX - XX століття): Н. Баленко, Л. Буніна, Л. Вовк, Л. Курило, М. Левківський, А. Павко, І. Прудченко, Н. Пузирьова, Т. Стоян, О. Сухий, С. Черняк та ін. Певні аспекти фрілологічної освіти 
вивчали Н. Дороніна, Н. Левицька, О. Місечко, Ю. Шелест та ін.

Виділення невирішених раніше частин загальної проблеми. Незважаючи на те, що багато науковців вивчали проблеми освіти, вищої освіти, діяльність окремих університетів на теренах України у 1850-1917 роках, проблема організаційно-методичних засад підготовки майбутніх фрілологів у зазначений вище період $€$ малодослідженою. Тому вважаємо доцільним дослідити це питання, залучивши архівні джерела.

Мета статті - дослідити ступінь висвітлення організаційно-методичних засад підготовки майбутніх фрілологів у вищих навчальних закладах України в 1850-1917 роках в архівних джерелах.

Виклад основного матеріалу. Матеріалами дослідження $€$ архівні джерела, які висвітлюють діяльність вищих навчальних закладів України в 1850-1917 роках. Ці матеріали містять інорормацію щодо організаційно-методичних засад підготовки майбутніх фрілологів у період, що досліджується: звіти університетів та фракультетів, офіційне листування, програми підготовки, розклади занять, матеріали інспектувань тощо. Зокрема, це документи і матеріали другої половини XIX - початку XX століття (звіти про заняття зі студентами та наукову роботу прооресорів університету за певні академічні роки, курси лекцій з різних предметів гуманітарного циклу, документи 3 організації закордонних відряджень, інструкції стипендіатам про організацію навчання, звіти про діяльність наукових товариств тощо).

Під час вивчення організаційно-методичних засад підготовки майбутніх фрілологів у вищих навчальних закладах України в 1850-1917 роках було відібрано п'ять, так званих класичних університетів, що знаходилися на території сучасної України. Тому вибір архівних установ та фрондів зумовлений насамперед географрічним принципом. Відомості, які відносяться до нашого дослідження, містяться у Центральному державному історичному архіві України (фр. 707); Центральному державному історичному архіві у м. Львові (ф. 319); Державному архіві Львівської області (ф. 26); Державному архіві м. Києва (фр. 16); Державному архіві Одеської області (ф. 44, 45); Державному архіві Харківської області (фр. 667); Державному архіві Чернівецької області (ф. 216).

Фонд 707. Управління Київського учбового округу міститься у Центральному державному історичному архіві України, м. Києві (далі - ЦДІАК України). Управління Київського навчального округу ЦДІАК України зберігає різні циркуляри та осріційне листування Міністерства народної освіти з Київським навчальним округом, документи про реорганізацію фракультету, протоколи засідання ради про конкурс на посади викладачів, справи, в яких містяться біографічні дані та згадка про науково-методичну роботу викладачів, розклади тощо: «Дело канцелярии г. Попечителя Киевского Учебного Округа по предоставлении Совета Университета Св. Владимира об объявлении на кафедре английского языка конкурса и определении учителя Фреймана (13 авг. 1842 - 1 окт. 1843 гг.)», «О результатах объявленных Университетом Св. Владимира конкурсов для замещения вакантной должности лекторов английского и итальянского языков», «Переписка Министерства с Киевским университетом, 1908 г.», «Расписание лекций историко-фрилологического фракультета Императорского университета св. Владимира в осеннем полугодии 1912 г.», «Обозрение преподавания в университете св. Владимира на 1912-1913 уч. г.», «Отчёт о практических занятиях по истории со студентами университета св. Владимира историкофрилологического фракультета экстраординарного профрессора А. Ставровского, 1859 г.», «По вопросу об открытии при историко-орилологических фракультетах университетов сверх основных трех или четырех отделений еще другие отделения для изучения специальностей» тощо.

Фонд 16. Київський університет Св. Володимира Державного архіву м. Києва зберігає найбільшу кількість документів Ради і правління, які стосуються організаційно-методичних засад навчального процесу. Передусім це програми курсів лекцій, фрормулярні та послужні списки, рапорти викладачів, адресовані декану фракультету про заплановані курси на навчальний рік, доповідні записки про перебіг подій на фракультеті, протоколи засідань деканату історико-фрілологічного фракультету за різні роки, копія інструкції про порядок нагляду за викладанням в університеті, затвердження навчально-методичної літератури радою історико-фрілологічного фракультету тощо.

Особливий інтерес для вивчення організаційно-методичних засад підготовки майбутніх фрілологів у 1850-1917 роках мають огляди викладання в Київському Імператорському університеті Св. Володимира, які були регулярними і з'являлися в кінці кожного року. У них міститься інформація стосовно циклів дисциплін, кількості годин, викладачів тощо. Програми викладання за півріччями дають можливість проаналізувати навантаження студентів, розклад; ознайомитися з переліком обов'язкових та фракультативних предметів, навчальним матеріалом, методичним забезпеченням тощо.

Державний архів Харківської області зберігає відомості, що стосуються проблематики дослідження, у фронді 667 «Харківський університет», а саме: опис 285 (1852-1916 рр.), опис 286 (18051917 рр.), опис 289 (1885-1887 рр.). Фонд містить такі матеріали: «Звіт про стан Харківського університету (1833), «Звіт дирекції училищ Чернігівської губернії про наслідки обслідування училищ» 
(1822), «Фінансовий звіт Подільського училища» (1833), «Історико-статистичний опис Харкова і Харківської губернії» (1859), «Справи про відкриття і закриття училищ, у тому числі СлобідськоУкраїнської гімназії і Харківського повітового училища» (1805), «Про призначення, переміщення і звільнення вчителів і чиновників училища, про заборону викладати в Київській гімназії польську мову» (1832); «Про організацію вчених архівних комісій» (1885), «Доповідь ректора Харківського університету на засіданні Ради професорів про участь студентів університету в революційних подіях у Харкові в жовтні 1905 р.», «Покажчик друкованих видань університету» (1805), «Протоколи засідань комітету редакторів ювілейних видань університету» (1903), «Листування з Харківським губернатором про заснування у Харкові фрілотехнічного товариства» (1811), «Атестати про закінчення Харківського університету» (1811, 1813-1834, 1840, 1912-1916), «Особиста справа студента фрілософрського відділення «Харківського університету поета Я.Г. Щоголева» (1843-1848), «Атестат щоголева про закінчення університету 1848 р. (копія). Особиста справа Пілсудського Іосифа Клеменса, студента медичного фракультету Харківського університету» (1885-1886), «Фінансові документи університету» (1918) [2].

Як можна побачити, дані описи охоплюють тільки деякі загальні відомості про діяльність університету і не містять справ, які стосуються підготовки майбутніх фрілологів у вищих навчальних закладах України в 1850-1917 роках.

Проте Центральною науковою бібліотекою Харківського національного університету імені В.Н. Каразіна створено електронний архів eScriptorium. Цей архів містить повні електронні версії (або окремі фррагменти) рідкісних видань, а саме документи, які присвячені історії, розвитку, діяльності Імператорського Харківського університету. Архів складається з таких розділів і колекцій: рукописні видання, видання кириличного друку, видання гражданського друку, українські видання, рідкісні та цінні видання, періодичні видання XIX століття, періодичні видання XX століття, історія університетів, «перша столиця», Харків очима сучасників, Харківські періодичні видання.

Найбільш цікавими та інформативними ресурсами для тематики нашого дослідження $є$ документи, видання, рукописи, які безпосередньо стосуються підготовки майбутніх фрілологів в Імператорському Харківському університеті 3 1850 по 1917 рік. Цей шар документів містить такі джерела: протоколи засідань ради Імператорського Харківського університету, розподіл лекцій та практичних занять в Імператорському Харківському університеті, огляди викладання в університеті, довідкові та ювілейні видання, розклади занять, підручники та енциклопедії, промови рек- торів та деканів, листування з Міністерством просвіти, правила для студентів університету, звіти про діяльність університету тощо [3].

Матеріали, які стосуються історії та діяльності Новоросійського Імператорського університету, містяться в Державному архіві Одеської області у фронді 42 та 45. Фонд 42 «Канцелярия попечителя Одесского учебного округа» містить загальні матеріали, які стосуються діяльності навчальних закладів Одеського навчального округу, а саме: циркуляри Міністерства народної просвіти, накази та розпорядження попечителя, протоколи засідань ради попечителя та його листування про перебіг навчального процесу, навчальні програми, програми екзаменів та зарахування тощо.

Фонд 45 містить 24 описи, які охоплюють період 3 дати заснування університету (1865 рік) до 1919 року. Описи 7-10 присвячені правлінню університету та охоплюють різноманітні питання, пов'язані з господарською, навчальною та організаційною діяльністю навчального закладу. Деякі описи містять інорормацію, яка безпосередньо стосується організаційно-методичних засад підготовки фрілологів в університетах України у 1850-1917 роках. Так, в описі 11 наявні документи «О разделении фризико-математического, историко-фрилологического и юридического фракультетов на отделения и об открытии технико-агрономического разряда» (1865 р.), «О преподавании наук в университете» (1865 р.); в описі 18: «Обозрение преподавания и распределения лекций» (1903 р.); в описі 19: «Отчет о состоянии и о деятельности историко-фрилологического, юридического, фризикоматематического фракультетов» (1913р.), «О подготовке преподавателей для университетов и институтов» (1912р.), «Распределение лекций на историко-фрилологическом фракультете» (1911 р.). Також в описах міститься інфрормація про студентські роботи, протоколи засідань ради університетів та клопотання фракультетів з різних питань.

Серед інтернет-джерел слід відзначити Електронну бібліотеку рідкісних видань Одеського національного університету імені І.І. Мечникова. Цей ресурс містить такі фонди: іменні колекції, картографрічні матеріали, періодичні видання, рідкісні та цінні видання XIX - XX століття, стародруки, Шевченкіана. Одним із найінформативніших для нашого дослідження джерелом є «Записки Імператорського Новоросійського університету», в якому містяться відомості щодо діяльності університету та його підрозділів, звіти роботи навчального закладу, протоколи засідань ради університету тощо, а також статті та дослідження викладачів та студентів університету, рецензії на твори та випускні роботи тощо [4].

Відомості щодо діяльності Львівського університету та його фракультетів містяться в Державному 
обласному архіві Львівської області у фронді 26, який називається «Університет ім. Яна Казимира у Львові». Для нашого дослідження інорормативними є справи, які охоплюють межі нашого дослідження та зберігаються в описі 22 під назвою «Університет ім. Франца I у Львові, що охоплює період з 1817 по 1918 роки. Опис 22 складається 3 документів консисторії (сенату), відомостей про фрілософський, юридичний, теологічний, медичний фракультети, а саме: циркуляри та розпорядження міністерств віросповідань і освіти Австрії і Польщі, протоколи засідань консисторії і сенату, рад профресорів фракультетів, навчальні програми і плани університету, програми фракультетів, розклади екзаменів на фракультетах університету, хроніки Львівського університету за різні періоди його існування, звіти про діяльність університету, ректорату і фракультетів тощо.

Опис 7 «Філософрький фракультет, гуманітарний фракультет» містить відомості за період з 1784 по 1924 роки. Особливий інтерес представляють проект закону про організацію вищих навчальних закладів (1849р.), правила навчання в університеті та тимчасовий дисциплінарний статут (1849 р.), навчальні програми студії і фракультету (1867-1907 рр.) тощо.

Для доступу до інтернет-джерел, які висвітлюють розвиток та діяльність Львівського університету та його фрілософського фракультету, зокрема, були досліджені фронди Ягелонської електронної бібліотеки (Jagiellońska Biblioteka Cyfrowa), неприбуткової бібліотеки «нтернет-архів» (Internet Archive), Великопольскої електронної бібліотеки (Digital Library of Wielkopolska), Федерації електронних бібліотек (Federacja Bibliotek Cyfrowych), які у вільному доступі містять рідкісні оцифровані історичні документи, статті, видання польською та німецькою мовами: «Перелік лекцій в Університеті ім. К.Ф. Франциска у Львові» («Wykaz wykładów odbywać się mających w C.K.Uniwersytecie imienia cesarza Franciszka we Lwowie»), «Журнал законів і національних правил для Королівства Галичина і Лодомерії разом 3 Великим князівством Краківським» («Dziennik Ustaw i Rozporządzeń Krajowych dla Królestwa Galicyi i Lodomeryi wraz z Wielkiem Księstwem Krakowskiem»), «Історія Львівського університету» («Historya Universitetu Iwowskiego»), «Склад університету та перелік лекцій у Львівському університеті імені Яна Казимира» («Skład Uniwersytetu i spis wykładów Uniwersytetu Jana Kazimierza we Lwowie»), «Збірник статутів університетів» («Zbiór ustaw uniwersyteckich»), «Постанова Міністерства релігій і просвітництва від 1 жовтня 1850 року» («Rozporządzenia Ministerstwa Wyznań i Oświecenia z 1 października 1850 roku»), «Академічні органи при К.К. Львів- ський університет: порядок проведення лекцій» («Akademische Behörden an der K.K. Universität zu Lemberg: sammt der Ordnung der Vorlesungen an derselben») тощо.

Державний архів Чернівецької області містить відомості про Чернівецький університет, які зберігаються у фонді 216, охоплюючи період із дня заснування університету (1875 р.) до 1940 року. У фронді знаходиться 7 описів з документами переважно німецькою та румунськими мовами. На жаль, у цьому фонді наявна переважно загальна інформація, яка стосується діяльності університету в цілому. Інформація щодо організаційнометодичних засад підготовки майбутніх фрілологів на фрілософрському фракультеті Чернівецького університету імені Франца Йосифа відсутня.

Також описи фонду 3 «Буковинська крайова управа» містять розпорядження університету та міністерства щодо урочистого відкриття університету, документи про профресорсько-викладацький склад, про створення екзаменаційних комісій, відомості щодо заробітної плати, присвоєння вчених звань, допуску до захисту, відрядження, розклади публічних лекцій тощо.

Відділ рідкісних книг та рукописів Чернівецького національного університету імені Юрія Федьковича налічує більше 70000 документів. Особливо цікавими $€$ історична колекція «Буковінензія», бібліотека Габсбургів, особисті бібліотеки вчених Констянтина Томащука, Євгена Козака, Василя Сімовича [1].

Висновки. Отже, огляд архівних джерел дає змогу цілісно охарактеризувати організаційнометодичні засади підготовки майбутніх фрілологів у вищих навчальних закладах України в 1850-1917 роках. Архівні джерела є невичерпним джерелом інфрормації щодо організації навчання майбутніх фрілологів, змісту, фрорми, методів, прийомів викладання дисциплін фрілологічного циклу. Джерельна база дослідження містить джерела, які були відібрані в процесі аналізу та вивчення документів в архівних установах України та електронних архівів, що є невід'ємною частиною сучасного дослідження.

\section{БІБЛІОГРАФІЧНИЙ СПИСОК:}

1. Відділ рідкісних книг та рукописів - Наукова бібліотека ЧНУ. URL: http://www.library.chnu.edu.ua/ index.php?page=ua/01about/02structure/06vrk (дата звернення: 15.06.2019).

2. Путівник Державного архіву Харківської області (рукопис) / упоряд. Л. Момот та ін. Харків, 2008. 1022 c.

3. eScriptorium - архив редких изданий и рукописей для науки и образования. URL: http://escriptorium. univer.kharkov.ua (дата звернення: 14.06.2019).

4. Library of rarebook at Odesa I.Mechnikov University. URL: http://rarebook.onu.edu.ua:8081 (дата звернення 14.06.2019). 